EDUARD MÜHLE

Uniwersytet w Münster

\title{
UWAGI O OGRANICZONEJ PRZYDATNOŚCI POJĘCIA „EUROPA ŚRODKOWO-WSCHODNIA” („OSTMITTELEUROPA”) W BADANIACH MEDIEWISTYCZNYCH
}

Historia jest przygodnym procesem, który ludzie - w tym historycy starają się sobie uświadomić, wyjaśnić i przyswoić z perspektywy czasu i z pomocą sensownych (re)konstrukcji. Świadomie bądź nieświadomie fundamentem owego procesu czynią interesy i konteksty swojej teraźniejszości. Skutkiem tego każda aktualizacja przeszłej rzeczywistości również ta, która odbywa się w ramach profesjonalnej historiografii znajduje się zawsze pod wpływem współczesnych kategorii społecznych i okoliczności politycznych. Pojęcie „Europy Środkowo-Wschodniej” stanowi dla owego fundamentalnego zjawiska z zakresu poznania historycznego znakomity przykład. Karierę zrobiło ono w ramach historiografii badającej wschodnią połowę kontynentu europejskiego, bez wątpienia w wyjątkowo zgodnym współbrzmieniu z politycznymi koniunkturami XX w. Przed XX stuleciem „Europa Środkowo-Wschodnia” nie istniała jako pojęcie czy wyobrażenie ani wewnątrz, ani na zewnątrz geograficznego obszaru wschodniej Europy Środkowej ${ }^{1}$. Do 1914/1918 r. to wielkie mocarstwa dynastyczne spod znaku trzech czarnych orłów oraz invented communities kształtujących się „narodów” ustalały i określały bowiem

${ }^{1}$ Starsze koncepcje Europy Środkowej, głoszone gdzieniegdzie już w XIX w., na ogół z perspektywy gospodarczo-liberalnej, umiejscowić należy w zupełnie innym kontekście; por. J. Le Rider, L'Europe Central. L'Idée germaniques de Mitteleuropa, Paris 1994; F. Hadler, Mitteleuropa - „Zwischeneuropa” - „Ostmitteleuropa”. Reflexionen über eine europäische Geschichtsregion im 19. und 20. Jahrhundert, „Slovanské štúdie” 1, 1996, s. 14-21; A. Miller, Die Erfindung der Konzepte Mittel- und Osteuropa, w: Wiener-Enzyklopädie des europäischen Ostens, t. 11: Europa und die Grenzen im Kopf, red. K. Kaser, Klagenfurt 2003, s. 139-163. 
realne, polityczne ramy odniesienia dla historiograficznych rozważań nad geograficznym obszarem Europy Wschodniej. Ani jedna, ani druga struktura nie za bardzo oprzeć się mogła na pojęciu „Europy Środkowo-Wschodniej", które kwestionowało (w przypadku absolutystycznych monarchii), względnie wykraczało poza przestrzeń oddziaływania ich polityki (w przypadku narodów walczących o samodzielną polityczną egzystencję) i tym samym zagrażało ich uroszczeniom. Znamienne, że po upadku wielkich mocarstw i po narodowo-państwowej emancypacji świata Słowian i Węgrów pojęcie „Europy Środkowo-Wschodniej” pojawiło się po raz pierwszy jako zmodyfikowane narzędzie niemieckiej polityki imperialnej. Jako takie służyło aż do lat czterdziestych XX w. konceptualizacji i legitymizacji niemieckiej obecności i ekspansji w Europie Wschodniej ${ }^{2}$. Znalazło to swoje odzwierciedlenie w niemieckojęzycznej historiografii, uprawianej w ramach niemieckiej „Ostforschung”, która postrzegała wschodnią część Europy Środkowej jedynie jako „ziemie etnicznie i kulturowo-niemieckie" i zrównywała "Ostmitteleuropę" z istniejącym rzekomo „niemieckim Wschodem” (,deutscher Osten”) ${ }^{3}$. W powojennej historiografii paradygmat ten od lat pięćdziesiątych ustępował z wolna miejsca nowej koncepcji „Europy Środkowo-Wschodniej”. Jej zamysłem było wyodrębnienie wschodniej części Europy Środkowej jako samodzielnego bytu historycznego i przeciwstawienie jej zarówno niedawnej dominacji niemiecko-narodowosocjalistycznej, jak i współczesnej, imperialnej dominacji sowieckiej. W tym celu poszukiwano historycznych cech strukturalnych, które charakteryzowałyby wschodnią część Europy Środkowej jako „część Europy o specyficznych właściwościach" i uprawomocniły tym samym ideę "Ostmitteleuropy” jako faktyczną rzeczywistość historyczną ${ }^{4}$. Paradygmat ów nawiązywał, co ciekawe, do koncepcji, które rozwijano w samym regionie, tj. we wschodniej

${ }^{2}$ E. Mühle, Putting the East in Order. German Historians and Their Attempts to Rationalize German Eastward Expansion During the 1930s and 1940s, w: Germans, Poland, and Colonial Expansion to the East. 1850 through the Present, red. R. L. Nelson, Basingstoke 2009, s. 95-120.

${ }^{3}$ E. Mühle, „Ostforschung”. Beobachtungen zu Aufstieg und Niedergang eines geschichtswissenschaftlichen Paradigmas, „Zeitschrift für Ostmitteleuropaforschung” 46, 1997, s. 317-350.

${ }^{4}$ W. Conze, Ostmitteleuropa. Von der Spätantike bis zum 18. Jahrhundert, red. i posłowie K. Zernack, München 1992, zwł.s. 5; K. Zernack, Alteuropäische Libertät und moderne Nation. Zur historischen Programmatik Ostmitteleuropas, w: Geisteswissenschaftliches Zentrum Geschichte und Kultur Ostmitteleuropas. Berichte - Beiträge 1996, Leipzig 1996, s. 19-33, cytat s. 22; G. Schramm, Ein Rundgespräch über „Ostmitteleuropa”. Vom sinnvollen Umgang mit einem Konzept für unsere Zunft, ,Jahrbücher für Geschichte Osteuropas” 48, 2000, s. 119-122; W. Eberhard, Ostmitteleuropa als historische Strukturregion, w: Perspektiven geisteswissenschaftlicher Forschung, Berlin [2003], s. 73-80. 
części Europy Środkowej, już w okresie międzywojennym i które kontynuowano potem na uchodźstwie, w czasie wojny i po niej. Również tutaj chodziło - w związku z polskimi i czeskimi wyobrażeniami politycznymi na temat nowej federalnej wspólnoty państwowej pomiędzy Bałtykiem a Morzem Czarnym - o uwypuklenie historycznej specyfiki społeczeństw wschodniej części Europy Środkowej i o wyraźne oddzielenie ich od regionu historycznego o odmiennych własnościach, jakim miał być bizantyńsko-ruski Wschód ${ }^{5}$. Co zrozumiałe, w socjalistycznej Europie Wschodniej koncepcje takie musiały po 1945 r. początkowo ucichnąć. Dopiero w późnych latach siedemdziesiątych i wczesnych osiemdziesiątych podjęto je na powrót w polskich, czeskich i węgierskich kręgach dysydenckich, stylizujących „Europę Środkową” na symbol przebudzenia demokratycznego, europejskiego społeczeństwa ${ }^{6}$. Sukces owego przebudzenia, którego zwieńczeniem stało się wejście państw wschodniej części Europy Środkowej do Unii Europejskiej w 2004 r., ponownie zmienił sposób traktowania koncepcji „Europy Środkowo-Wschodniej”. Wydaje się, że wraz z kolejnymi przełomami politycznymi jego kariera dobiegła tymczasem końca. Podobnie jak w XIX w. wielkie mocarstwa dynastyczne i kształtujące się narody nie potrzebowały idei samodzielnej Europy Środkowo-Wschodniej jako regionu historycznego i w związku z tym nie potrafiły takiej koncepcji sformułować, tak teraz, na początku XXI w., zintegrowana politycznie Europa i jej wschodnie państwa członkowskie zdają się nie potrzebować „wielkiej narracji”, która konstruowałaby „Europę Środkowo-Wschodnią” jako rzeczywisty byt historyczny, odróżniający się swoją specyfiką od pozostałych części Europy. W każdym razie bieżąca historiografia od dawna wysuwa już na plan pierwszy inne paradygmaty. Na czasie jest ostatnio historia wzajemnych związków (historie croisée, entangled history), historia transkulturowa i transnarodowa, a także powszechna historia porównawcza Europy ${ }^{7}$. Przy zastosowaniu takich perspektyw to raczej wspólne doświadczenia historyczne zjednoczonej Europy niż dzielące, wyodrębniające właściwości poszczególnych regionów historycznych wysuwają się na pierwszy plan zainteresowań badawczych.

${ }^{5}$ Por. J. Kłoczowski, Europa Środkowowschodnia w historiografii krajów regionu, Lublin 1993, zwł. s. 6-24.

${ }^{6} \mathrm{Na}$ profesjonalnej płaszczyźnie naukowej owo „odkrycie” Europy Środkowo-Wschodniej znalazło swój wyraz przede wszystkim w eseju Jenő Szücsa: J. Szücs, Trzy Europy, Lublin 1995 (tł. z wyd. franc. 1985, oryg. węg. 1981).

${ }^{7}$ Por. J. Kocka, Das östliche Mitteleuropa als Herausforderung für eine vergleichende Geschichte Europas, „Zeitschrift für Ostmitteleuropa-Forschung” 49, 2000, s. 159-174; G. Klaniczay, Une Europe centrale au Moyen Âge? Réflexions historiques et recherches sur l'histoire croisée, w: East-Central Europe in European History. Themes and Debates, red. J. Kłoczowski, H. Łaszkiewicz, Lublin 2009, s. 109-130. 
Skoro zatem „Europa Środkowo-Wschodnia” okazuje się konstruktem historyków, odzwierciedlającym przede wszystkim - choć oczywiście nie wyłącznie - oczekiwania i wyobrażenia konkretnej teraźniejszości $^{8}$, co w takim razie oznacza to dla dzisiejszych badań historycznych nad polskim, czeskim i węgierskim średniowieczem? Co pozostaje wówczas z owych strukturalnych podobieństw, które historycy Europy Środkowo-Wschodniej zidentyfikowali jako własności pozwalające - w ich mniemaniu - mówić również w odniesieniu do średniowiecza o pewnym szczególnym, rzeczywistym regionie historycznym, jakim miała być Europa Środkowo-Wschodnia? Jeśli wyszczególnimy rzeczone własności, tak jak je np. z perspektywy niemieckojęzycznej mediewistyki zestawił Christian Lübke9, otrzymamy następującą wiązkę kryteriów, które z grubsza w chronologicznym układzie, od wczesnego do późnego średniowiecza - wyróżniać miały wschodnią część Europy Środkowej jako samodzielny region historyczny: 1) brak przynależności do cywilizacji rzymskiej i świata wczesnochrześcijańskiego; 2) słowiańska homogeniczność przejawiająca się w języku i kulturze materialnej; 3) akefaliczna organizacja władcza w ramach „społeczności bez państwa”; 4) przekształcenie się owych społeczności w społeczności scentralizowane z wyraźną strukturą władzy; 5) chrystianizacja; 6) multietniczne miejsca handlowe i szczególna otwartość na obcych; 7) oparcie na drużynach wojskowych w budowie struktur władzy; 8) przeforsowanie niekwestionowanego jedynowładztwa w ramach jednej dynastii; 9) organizacja władzy z pomocą ius ducale i organizacji służebnej; 10) organizacja kościelna oparta na władztwie ziemskim i wsparta kultem świętych krajowych; 11) włączanie obcych świeckich i duchownych do elit „państwa” i Kościoła; 12) prawne i gospodarcze ujednolicenie poprzez kolonizację wewnętrzną i wprowadzenie prawa niemieckiego.

${ }^{8}$ Por. E. Mühle, East Central Europe as a Concept of German Historical Research, w: Europe Centrale entre l'est et l'ouest / East Central Europe between East and West, red. J. Kłoczowski, Lublin 2005, s. 13-29.

${ }^{9}$ C. Lübke, Die Prägung im Mittelalter. Frühe ostmitteleuropäische Gemeinsamkeiten, „Comparativ. Leipziger Beiträge zur Universalgeschichte und vergleichenden Gesellschaftsforschung" 8, 1998, 5: Geschichte und Kultur Ostmitteleuropas in vergleichender Absicht, s. 14-24; idem, Mitteleuropa, Ostmitteleuropa, östliches Europa. Wahrnehmung und frühe Strukturen eines Raumes, w: Die „Blüte” der Staaten des östlichen Europa im 14.Jahrhundert, red. M. Löwener, Wiesbaden 2004, s. 15-43. Dla perspektywy środkowoeuropejskiej por. J. Kłoczowski, Młodsza Europa. Europa Środkowo-Wschodnia w kręgu cywilizacji chrześcijańskiej średniowiecza, Warszawa 1998; M. Font, Im Spannungsfeld der christlichen Großmächte. Mittel- und Osteuropa im 10.-12.Jahrhundert, Herne 2005; dla perspektywy anglosaskiej por. R. Bartlett, Tworzenie Europy. Podbój, kolonizacja i przemiany kulturowe 950-1350, Poznań 2003 (oryg. ang. 1993). 
Dwie sprawy rzucają się w oczy w owym katalogu kryteriów. Po pierwsze, pokrywa się on z tradycyjnym kanonem zagadnień mediewistyki, w którym poza polem zainteresowań znajdują się ciekawe tematy współczesnej nauki. Te zaś - chodzi o formy reprezentacji władzy i komunikacji, mechanizmy zażegnywania konfliktów i zaprowadzania pokoju, rozprzestrzenianie się i oddziaływanie monastycyzmu, rolę memorii i fundacji, przemiany prowadzące od kultury oralnej do piśmiennej, by wskazać tylko kilka przykładów - wydobywają na powierzchnię właśnie raczej strukturalne podobieństwa pomiędzy Zachodem i Wschodem, odsuwając na drugi plan postulowaną „specyfikę” Europy Środkowo-Wschodniej ${ }^{10}$. Po drugie, jeśli przyjrzeć się bliżej, to w przytoczonych cechach strukturalnych tylko z pewnymi zastrzeżeniami chodzi o zjawiska, które faktycznie działały na tyle wyróżniająco na zewnątrz i na tyle integrująco do wewnątrz, by móc stworzyć w średniowieczu rzeczywisty, samodzielny region historyczny określany jako „Europa Środkowo-Wschodnia”.

Ograniczone ramy niniejszego tekstu nie pozwalają tu na szczegółową dekonstrukcję owych właściwości. Pars pro toto omówmy zatem tylko jedną ze sztandarowych cech szczególnych rzekomej specyfiki Europy Środkowo-Wschodniej w średniowieczu - tzw. ius ducale i powiązaną z nią „organizację służebną”. Również ten wzorzec wyjaśniający okazał się tymczasem, jak się zdaje, „dzieckiem swoich czasów” i interpretacją znajdującą się w znacznym stopniu pod wpływem ogólnej sytuacji panującej od lat pięćdziesiątych do osiemdziesiątych. Nowsze badania, drążące głębiej i stosujące perspektywę porównawczą ukazują w każdym razie, że „państwa” Arpadów, Przemyślidów i Piastów nie były w żadnym razie tak przesycone duchem absolutyzmu i centralizacji, jak była o tym przekonana nauka w owych dekadach; widać też ponadto, że narzędzia sprawowania władzy ujęte pojęciami ius ducale i organizacja służebna występowały w podobnych formach również gdzie indziej ${ }^{11}$. Owa relatywizacja jednej z niezwykle rzekomo charakterystycznych dla Europy

${ }^{10}$ Por. P. Górecki, Medieval Poland in its World, Then and Today, w: East-Central Europe in European History, s. 157-192, zwł. s. 167-168; P. Górecki, N. van Deusen, Toward a New Cultural History of East Central Europe?, w: Central and Eastern Europe in the Middle Ages. A Cultural History, red. iidem, London 2009, s. 192-212, 285-287; G. Klaniczay, Von Ostmitteleuropa zu Westmitteleuropa. Eine Umwandlung im Hochmittelalter, w: Böhmen und seine Nachbarn in der Přemyslidenzeit, red. I. Hlaváček, A. Patschovsky, Ostfildern 2011, s. 17-48.

${ }^{11}$ F. Curta, The archeology of early medieval service settlements in Eastern Europe, w: Central and Eastern Europe in the Middle Ages. A Cultural History, s. 30-41, 221-227; „Lelewel-Gespräche” 2011, 4: Gab es das „Dienstsystem” im mittelalterlichen Polen - oder was war das ius ducale? 5. Joachim-Lelewel-Gespräch des Deutschen Historischen Instituts in Warschau, red. E. Mühle 〈http://www.perspectivia.net/content/publikationen/lelewel-gespraeche/ 4-2011> (dostęp: 14 XII 2013). 
Środkowo-Wschodniej form sprawowania władzy potwierdza się również dzięki wynikom nowszych badań, skupiających się na stosowaniu rytuału i komunikacji symbolicznej ${ }^{12}$. Te i inne przykłady, których ze względu na ograniczoną objętość tekstu nie sposób tu omówić, każą przypuszczać, że najsensowniejsze wydaje się zarzucenie poszukiwań średniowiecznej „Europy Środkowo-Wschodniej” w sensie „części Europy o określonej specyfice". Zamiast tego należałoby się skupić na otwartym, porównawczym, zorientowanym tematycznie badaniu głównych fenomenów historii średniowiecznej, nie koncentrującym się z założenia na jednym, ograniczonym geograficznie subregionie Europy, lecz analizującym różnice i podobieństwa, równoczesność i nierównoczesność, zmianę i zastój w Europie, w oderwaniu od owych wyobrażonych podziałów na Wschód i Zachód, które spowodowały zakotwiczenie się w naszych głowach pojęcia „Europy Środkowo-Wschodniej" jako wytworu przezwyciężonych już wszak uwarunkowań politycznych.

12 Z. Dalewski, Rytuał i polityka. Opowieść Galla Anonima o konflikcie Bolesława Krzywoustego ze Zbigniewem, Warszawa 2005; idem, Begräbnis des Herrschers. Ritual und Streit um die Thronfolge in Polen des frühen Mittelalters, „Frühmittelalterliche Studien” 43, 2009, s. 327-347; idem, Ritual im Wandel. Herzogserhebungen der polnischen Herrscher um die Wende vom 12. zum 13. Jahrhundert, w: Ritualisierung politischer Willensbildung. Polen und Deutschland im hohen und späten Mittelalter, red. W. Fałkowski, Wiesbaden 2010, s. 79-99. 